\title{
ANALISIS PENGARUH PRODUCT PLACEMENT TERHADAP WORD OF MOUTH ATAS MEREK SPEEDY PADA ACARA LIVE SHOW NBL INDONESIA
}

\author{
Alfitri Jayanti, Rohmat Dwi Jatmiko, Sri Nastiti Andharini \\ Department of Management FEB UMM \\ E-mail: mollyjayanti@gmail.com
}

\begin{abstract}
The research aims to analyze the effect of product placement on word of mouth at NBL Indonesia. Population is audience of NBL Indonesia. Sample taken were 100 respondents using purpossive sampling method. Simple Linear Regression used as an analytical tool. The result shows that product placement has a positive effect on word of mouth.
\end{abstract}

Keywords: Product Placement, and Word of Mouth, NBL Indonesia

\section{PENDAHULUAN}

Bone dalam Harsasi, (2006) mengemukakan bahwa WoM mengacu pada suatu pertukaran pemikiran, gagasan, atau komentar diantara dua orang atau lebih dimana mereka bukan sumber pemasaran. Selain itu WoM cenderung lebih sulit dikontrol. Padahal WoM bisa jadi lebih efektif dibandingkan iklan. Menurut Anwar (2011), sikap konsumen yang positif dipengaruhi oleh Word of Mouth (WoM) yang positif. Handayani (2010), bahwa konsumen Indonesia yang puas terhadap suatu produk akan menceritakan kepada 5 sampai 15 orang tergantung kepada jenis dan target pasar yang dibidik.

Studi oleh US Office of Consumer Affairs (Kantor Urusan Konsumen Amerika Serikat) menunjukkan bahwa WoM memberikan efek yang signifikan terhadap perilaku konsumen. Dalam studi tersebut disebutkan bahwa secara rata-rata, satu konsumen tidak puas akan mengakibatkan sembilan calon konsumen lain yang akan menyebabkan ketidakpuasan. Sedangkan konsumen yang puas hanya akan mengabarkan kepada lima calon konsumen lain (Knauer, 1992).

Riset Herr et al (1991) dalam Mangold et al (1999), menemukan bahwa WoM memiliki impact yang lebih besar daripada informasi tertulis. Efek dari WoM sangat besar, bahkan banyak pemasar yang telah memanfaatkannya. WoM memiliki efek yang kuat dan besar karena berasal dari sumber yang terpercaya, pengaruhnya bahkan diakui lebih besar dari pengaruh iklan di televisi (Fahima, 2007).

Product placement dikatakan berkaitan dengan word of mouth, hal ini dapat dijelaskan bahwa saat pesan product placement sampai kepada audience, baik melalui film ataupun media entertainment lainnya. Product placement tersebut adalah sebuah 
cara untuk meningkatkan promosi sebuah produk atau jasa dengan menampilkan produknya dengan kesan bahwa keberadaan produk tersebut seolah-olah menjadi bagian dari cerita film dan acara televisi (Belch and Belch, 2012).

Product yang digunakan oleh seseorang yang terpercaya, dapat mempengaruhi word of mouth audience, sebagai contoh: pada umumnya keseluruhan tim basket NBL Indonesia menggunakan merek sepatu Nike. Hal ini mampu menciptakan word of mouth positif kepada audience, yang memunculkan presepsi bahwa brand Nike yang digunakan oleh pemain basket merupakan merek sepatu basket terbaik.

Menggunakan product placement sebagai suatu strategi untuk mempengaruhi audience merupakan cara yang tepat di dalam live show NBL Indonesia. Balasubramanian, et al (2006) yang menyatakan product/brand placement sebagai contoh jelas/menonjol dari hybrid message atau upaya mempengaruhi audience yang dilakukan dengan biaya tertentu, namun tidak teridentifikasi sebagai sponsor. Product Placement dari Telkom Speedy mampu menarik perhatian penonton di dalam acara NBL Indonesia, dan membawa penonton masuk di dalam bagian acara tersebut.

Setelah mengamati product placement dari Telkom dengan merek Speedy yang ada di setiap acara NBL Indonesia, produk yang bermerek Speedy ini telah muncul sejak tahun 2012 hingga tahun 2014 mendatang akan menjadi sponsor utama NBL. Jumlah kemunculan produk ini baik di booth depan Gedung Olahraga pada saat acara NBL Indonesia berlangsung, games, lapangan, dan wallpaper GOR dipenuhi sebagian oleh brand Speedy. Product placement yang dilakukan oleh perusahaan Telkom ini, mampu mengikuti keinginan penonton dan support berbagai konsep acara di dalam NBL Indonesia.

Penelitian ini menggunakan acara live show/live match NBL (National Basketball League) Indonesia sebagai media yang akan dijadikan contoh studi kasus dalam mengaplikasikan product placement pada acara live show. Pada acara tersebut menampilkan banyak produk/merek yang dibawakan oleh player club basket beserta tim dan juga presenter. Dengan promosi melalui produk placement pada akhirnya mau tidak mau penonton tentu akan melihat produk-produk yang ditampilkan dan digunakan NBL Indonesia.

Produk atau merek yang ditampilkan adalah Speedy, Mikasa, League, Koran Jawa Pos dan Bank BRI. Secara tidak langsung muncul beberapa $\mathrm{brand} / \mathrm{merek}$ yang digunakan oleh player club basket nasional tersebut diantaranya sepatu Nike, Jersey klub CLS Knights yaitu Piero dan Ubaya, Jersey klub Satria Muda dengan brand BritAma dari Bank BRI, dan klub Aspac Jakarta dengan sponsor M88.

Peneliti memilih acara live show NBL Indonesia sebagai objek penelitian, karena beberapa alasan pendukung, NBL Indonesia merupakan acara live show yang menempati peringkat pertama dalam industri olahraga event, yang umumnya menjadi daya tarik bagi 
pengiklan karena menjadi gambaran akan popularitas acara live show. Acara live show dengan format industri olahraga ini, banyak diminati semua kalangan dan umur, pada umumnya mayoritas diminati remaja hingga dewasa.

\section{TINJAUAN PUSTAKA}

Tandiono dan Rumambi (2013) menganalisis dan mengetahui efektifitas product placement dan brand recall yang digunakan dalam film Twilight Saga Breaking Dawn: Part 2 terhadap sikap audience. Melihat faktor-faktor di dalam sikap audience terhadap product placement dan brand recall di dalam film tersebut. Metode analisis data menggunakan metode analisis deskriptif, analisis faktor-faktor, dan analisis korelasi.

Penelitian Purbarani (2013) yaitu menganalisis pengaruh word of mouth terhadap keputusan pembelian mahasiswa pada produk blackberry. Metode analisis data menggunakan metode analisis deskriptif kuantitatif, analisis korelasi, dan analisis regresi linier yang digunakan untuk mengukur pengaruh word of mouth pada keputusan pembelian.

Product Placement, menurut

Belch dan Belch (2007), product placement adalah sebuah cara untuk meningkatkan promosi sebuah produk atau jasa dengan menampilkan produknya dengan kesan bahwa keberadaan produk tersebut seolah-olah menjadi bagian dari cerita film dan acara televisi. Meningkatnya strategi product placement mengindikasikan bahwa pengiklan menggunakan teknik ini untuk mempengaruhi brand attitude konsumen. Namun definisi diatas perlu di evalusi ulang, karena product placement juga dapat dilakukan melalui video musik, program radio, lagu-lagu, video games, teater, novel, majalah, dan lain sebagainya. (Gupta and Gould, 1997).

Dalam sebuah penelitian Argan et al (2007), sikap konsumen dilihat berdasarkan empat dimensi membangun, yaitu, Attention (Perhatian), sejauh mana audience dapat memperhatikan dan mengingat product/brand placement dalam film, begitu juga apabila merek tersebut ditempatkan menyatu dengan alur cerita. Acceptance (Penerimaan), bagaimana penerimaan audience terhadap penempatan product/ brand placement dalam film. Reference (Referensi), ketertarikan audience untuk menggunakan product/brand placement dalam film yang dipakai oleh tokoh dalam film. Ethics and Regulation (etika dan peraturan), ketergangguan audience terhadap product/ brand placement yang muncul dalam film.

Word of Mouth menurut Balter and Bultman (dalam Purba, 2010) merupakan "everybody talks about products and services, and they talk about them all the time. Word of mouth is not about identifying a small subgroup of highly influential or wellconnected people to talk up a product or service. It's not about mavens or bees or celebrities or people with specialist knowledge. It's about everybody." Yang berarti setiap orang berbicara mengenai produk dan jasa, merek membicarakannya setiap saat.

Word of Mouth adalah sebuah strategi pemasaran untuk membuat pelanggan membicarakan (do the talking), mempromosikan (do the 
promotion) dan menjual (do the telling) yang disingkat menjadi TAPS (Talking, Promoting dan Selling) dan menjadi acuan dasar dari penelitian word of mouth marketing pertama di Indonesia. Tiga tahapan WOM menurut Sumardi (2009) adalah TAPS (Talking, Promoting, Selling), dimana membicarakan (talking) adalah tahapan seorang konsumen membicarakan sebuah produk atau merek kepada konsumen lain, mempromosikan (promoting) ketika seorang konsumen bukan hanya sekedar membicarakan merek/produk tapi juga bersedia untuk mempromosikannya kepada konsumen lain, menjual (selling) adalah tahapan dimana seorang konsumen mau untuk menjualkan merek/produk tersebut terhadap orang lain.

Word of mouth (komunikasi dari mulut ke mulut) sekarang ini menjadi sangat efektif karena perkembangan teknologi yang begitu pesat membuat, para konsumen dengan mudah membicarakan suatu produk, selain ketika bertatap muka, word of mouth juga dapat terjadi melaui media internet melalui jejaring sosial dan juga media handphone yang memungkinkan terjadinya word of mouth. Yang akhirnya teknologi makin mempercepat sampainya bahasa lisan.

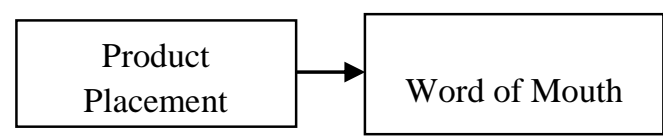

Gambar 1. Kerangka Konseptual

Model konseptual yang dikembangkan dalam penelitian ini menggambarkan variabel yang akan diteliti yaitu korelasi antara product placement dengan word of mouth atas merek speedy pada acara NBL Indonesia.

\section{METODE PENELITIAN}

Penelitian ini dilakukan di GOR Bimasakti yang berada di Jalan Kolonel Slamet Supriyadi No.91 Kecamatan Sukun, Malang. Peneliti memilih lokasi tersebut dikarenakan GOR Bimasakti merupakan lokasi berlangsungnya acara NBL Indonesia setiap tahun pada Seri Malang. Jenis penelitian ini adalah jenis penelitian deskriptif untuk menjelaskan fenomena aktivitas pemasar dalam melakukan product placement yang berhubungan dengan komunikasi word of mouth audience atas merek Speedy yang terjadi pada acara live show NBL Indonesia.

Populasi dalam penelitian ini adalah penonton live NBL Indonesia, dengan teknik nonprobability sampling. Nonprobability sampling adalah teknik pengambilan sampel yang tidak memberi peluang/kesempatan sama bagi setiap unsur atau anggota populasi untuk dipilih menjadi sampel.

Beberapa kriteria responden yang digunakan dalam populasi adalah sebagai berikut a) Pernah menonton NBL Indonesia, b) Berusia 10-45 tahun, c) Fans NBL Indonesia, d) Mengikuti perkembangan dan perubahan acara NBL Indonesia. Pengambilan sampel yang digunakan dalam penelitian ini adalah purposive sampling, yaitu penentuan sampel dengan pertimbangan tertentu, seperti penentuan karakteristik dan kriteria responden yang akan diteliti. Operasionalisasi variabel penelitian berarti menjabarkan variabel atau sub variabel menjadi konsep, dimensi, 
indikator, ukuran, dan lain-lain yang diarahkan untuk memperoleh nilai variabel penelitian (Purbarani, 2013).

Pertama, Product Placement yang merupakan kegiatan menyisipkan produk dengan merek tertentu dalam film. Attention (X1) Speedy menarik perhatian penonton sebagai sponsor acara NBL Indonesia. Logo Speedy menarik perhatian penonton dalam acara NBL Indonesia. Acceptance (X2) Speedy bisa diterima atas kontribusinya dalam acara NBL Indonesia.

Speedy dapat diterima penonton sebagai sponsor acara NBL Indonesia. Reference (X3) Speedy digunakan oleh penonton NBL Indonesia. Speedy biasa dimanfaatkan fans untuk menonton live streaming (siaran langsung) NBL Indonesia. Ethics \& Regulations (X4) Promosi Speedy tidak menggangu jalannya acara NBL Indonesia. Sponsorship Speedy telah mengikuti tema acara NBL Indonesia.

Word of Mouth, Talking (Y1)

Speedy menjadi pembicaraan penonton NBL Indonesia. Speedy menjadi pembicaraan penonton sebagai sponsor utama NBL Indonesia. Promoting (Y2) Pempromosian Speedy instan card digunakan untuk live streaming NBL Indonesia. Pempromosian Speedy instan card menarik penonton di kota tempat berlangsungnya acara NBL Indonesia. Selling (Y3) Speedy merekomendasikan produk Speedy instan card kepada penonton NBL Indonesia. Penjualan Speedy instan card dapat digunakan untuk menarik penonton NBL Indonesia.

Sumber data dalam penelitian ini adalah data primer yang dikumpulkan dari sumber pertama yang diperoleh langsung pada saat pengisian kuesioner responden. Teknik pengolahan Data pada penelitian ini ada empat tahap yaitu, Editing adalah memilih atau mengambil data yang perlu dan membuang data yang dianggap tidak perlu, untuk memudahkan perhitungan dalam pengujian hipotesis. Coding adalah proses pemberian kode tertentu terhadap instrumen dari kuesioner untuk di kelompokan ke dalam kategori yang sama.

Scoring adalah suatu kegiatan pemberian nilai berupa angka pada jawaban pertanyaan agar memperoleh data kuantitatif untuk pengujian hipotesis. Pada penelitian ini skala pengukuran jawaban kuesioner menggunakan skala interval 1-5 untuk menganalisis jawaban data dari responden tersebut. Analisis Tabulasi adalah pengelompokan atas jawaban dengan menghitung dan menjumlahkan sampai terwujudnya dalam bentuk tabel, sehingga dapat melihat hasil penelitian dengan jelas.

Uji Validitas Instrumen yang valid berarti alat ukur yang digunakan untuk mengukur validitas data. Instrumen dikatakan valid apabila koefisien korelasinya $\geq 0,3$ dan $\alpha=$ 0,05 (Sugiyono, 2010:172). Uji reliabilitas dimaksudkan untuk mengetahui apakah kuesioner dapat diandalkan dalam mengukur suatu jawaban dari suatu pertanyaan.

Kuesioner yang reliabel berarti mampu mengungkapkan data yang dapat dipercaya. Uji Hipotesis dirumuskan sebagai berikut:

$\mathrm{H}_{0}: \quad \mathrm{b}_{\mathrm{i}}=0:$ product placement berpengaruh positif dan tidak signifikan terhadap word of 
mouth produk Speedy.

$\mathrm{H}_{1}: \mathrm{b}_{\mathrm{i}} \neq 0$ : product placement berpengaruh positif dan signifikan terhadap word of mouth produk Speedy.

Uji Signifikan Simultan (Uji F) Pengujian hipotesis dengan uji $F$ ini bertujuan untuk mengetahui pengaruh bersama-sama variabel independen terhadap variabel dependen (Bhuono Agung $\mathrm{N}$ 2005:53). Kriteria pengambilan keputusan yang digunakan untuk hipotesis adalah $\mathrm{H}_{0}$ diterima jika Fhitung $\leq$ Ftabel. $\mathrm{H}_{1}$ diterima jika Fhitung $>$ Ftabel

\section{HASIL PENELITIAN DAN PEMBAHASAN}

Responden dalam penelitian ini adalah 100 penonton NBL Indonesia di kota Malang, yang telah memenuhi syarat sebagai penonton setia mengikuti perkembangan NBL Indonesia.

Tabel 1. Responden Berdasarkan Jenis Kelamin

\begin{tabular}{ccc}
\hline $\begin{array}{c}\text { Jenis } \\
\text { Kelamin } \\
\text { Responden }\end{array}$ & $\begin{array}{c}\text { Jumlah } \\
\text { Responden } \\
\text { (Orang) }\end{array}$ & $(\%)$ \\
\hline Laki-laki & 43 & $43 \%$ \\
Perempuan & 57 & $57 \%$ \\
\hline Total & 100 & $100 \%$ \\
\hline
\end{tabular}

Sumber: Data diolah 2013

$\begin{array}{ccr}\text { Tabel } & 1 & \text { memberikan } \\ \text { informasi } & \text { bahwa } & \text { mayoritas }\end{array}$ responden memiliki jenis kelamin Perempuan dengan jumlah 57 orang atau $57 \%$. Hal ini dikarenakan NBL Indonesia merupakan liga basket antar klub nasional yang keseluruhan pemain adalah laki-laki. Pemain NBL Indonesia inilah yang mampu menarik perhatian wanita dengan kemampuan dan skill yang dimiliki oleh setiap pemain untuk datang menonton dan memberikan support secara langsung untuk pemain atau klub yang diidolakan.

Usia responden mempengaruhi sifat dan tindakan responden dalam mengikuti perkembangan dan antusiasme terhadap NBL Indonesia. Gambaran mengenai usia responden dapat dilihat pada Tabel 2

Tabel 2. Responden Berdasarkan

\begin{tabular}{|c|c|c|}
\hline \multicolumn{3}{|c|}{ Usia } \\
\hline Usia & Jumlah & $(\%)$ \\
\hline $\begin{array}{c}\text { Responden } \\
\text { (Tahun) }\end{array}$ & $\begin{array}{c}\text { Responden } \\
\text { (Orang) }\end{array}$ & \\
\hline$<15$ & 4 & $4 \%$ \\
\hline Tahun & & \\
\hline $15-20$ & 43 & $43 \%$ \\
\hline Tahun & & \\
\hline $21-25$ & 51 & $51 \%$ \\
\hline Tahun & & \\
\hline $26-30$ & 2 & $2 \%$ \\
\hline Tahun & & \\
\hline$>30$ & - & - \\
\hline Tahun & & \\
\hline Total & 100 & $100 \%$ \\
\hline
\end{tabular}

Sumber: Data diolah 2013

Tabel 2 memberikan informasi bahwa mayoritas responden berusia $21-25$ tahun dengan jumlah 51 orang atau sebesar $51 \%$. Hal ini dikarenakan pada usia ini sebagian besar penonton NBL adalah mahasiswa, dimana hal tersebut didukung oleh predikat kota Malang merupakan salah satu kota dengan banyak perguruan tinggi. Intensitas liga dan kompetisi basket masih sangat diminati oleh sebagian besar mahasiswa yang menggemari olahraga basket.

Tabel 3. Responden Berdasarkan Tingkat Pendidikan 


\begin{tabular}{|c|c|c|}
\hline $\begin{array}{l}\text { Pendidikan } \\
\text { Responden }\end{array}$ & $\begin{array}{l}\text { Jumlah } \\
\text { Responden } \\
\text { (Orang) }\end{array}$ & $\begin{array}{c}\text { Persentase } \\
(\%)\end{array}$ \\
\hline $\begin{array}{l}\text { SD } \\
\end{array}$ & - & - \\
\hline SMP & 3 & $3 \%$ \\
\hline SMA/SMK & 44 & $44 \%$ \\
\hline $\begin{array}{c}\text { DIPLOMA- } \\
3\end{array}$ & 3 & $3 \%$ \\
\hline $\begin{array}{l}\text { SARJANA } \\
(\mathrm{S} 1, \mathrm{~S} 2, \mathrm{~S} 3)\end{array}$ & 50 & $50 \%$ \\
\hline Total & 100 & $100 \%$ \\
\hline
\end{tabular}

Tabel 3 memberikan informasi bahwa mayoritas responden berpendidikan Sarjana yaitu sebanyak 50 responden atau sebesar 50\% dan dominasi kedua oleh pelajar SMA/SMK sebesar 44 responden atau sebesar $44 \%$. Hal ini mendukung penjelasan pada Tabel 3 bahwa mayoritas penonton NBL Indonesia di dominasi oleh mahasiswa dan pelajar SMA/SMK yang tersebar diseluruh Kota Malang.

Hasil Uji Validitas Pengujian instrumen penelitian ini terhadap 100 responden menunjukkan semua item pertanyaan untuk variabel X Product Placement yaitu (attention, acceptance, reference, ethics \& regulations) dan variabel Y Word of Mouth (talking, promoting, selling) memiliki nilai korelasi yang lebih besar dari 0,3 dan siginifikansi korelasi < 0,05 maka dapat dikatakan bahwa semua item pada pernyataan tersebut adalah valid.

Hasil uji reliabilitas pada dimensi ini memiliki nilai cronbach alpha diatas 0,6 yang menunjukkan nilai reliabel yang tinggi. Product placement yaitu konstruk attention sebesar 0,811, acceptance sebesar 0,772 , reference sebesar 0,770 , ethics \& regulations sebesar 0,644. Pada indikator dari word of mouth konstruk talking sebesar 0,759 , promoting sebesar 0,713, dan selling sebesar 0,753. Dari hasil tersebut maka dapat dikatakan bahwa masing-masing konstruk reliabel tinggi karena $\alpha>0,6$.

Tabel 4. Analisis Rentang Skala dimensi Attention (Perhatian)

\begin{tabular}{|c|c|c|c|c|c|c|c|c|c|}
\hline \multirow[t]{2}{*}{ Respon (Attention) } & \multicolumn{5}{|c|}{ Skor Jawaban } & \multirow[t]{2}{*}{$\begin{array}{c}\text { Total } \\
\mathrm{N}\end{array}$} & \multirow[t]{2}{*}{ Mean } & \multirow[t]{2}{*}{$\begin{array}{c}\text { Skor } \\
\text { Rentang } \\
\text { Skala } \\
\end{array}$} & \multirow[t]{2}{*}{$\begin{array}{c}\text { Kriteria } \\
\text { Penilaian }\end{array}$} \\
\hline & STS & TS & $\mathrm{N}$ & $\mathrm{S}$ & SS & & & & \\
\hline $\begin{array}{l}\text { Perhatian terhadap } \\
\text { Sponsor }\end{array}$ & 1 & 7 & 16 & 44 & 32 & 100 & 3,99 & 399 & Setuju \\
\hline Perhatian Logo & 1 & 10 & 25 & 43 & 21 & 100 & 3,73 & 373 & Setuju \\
\hline $\begin{array}{c}\text { Kesesuaian Konsep } \\
\text { Acara }\end{array}$ & 0 & 1 & 28 & 54 & 17 & 100 & 3,87 & 387 & Setuju \\
\hline $\begin{array}{l}\text { Perhatian brand } \\
\text { Produk }\end{array}$ & 0 & 3 & 15 & 47 & 35 & 100 & 4,14 & 414 & Setuju \\
\hline $\begin{array}{c}\text { Perhatian } \\
\text { kesesuaian tema }\end{array}$ & 0 & 5 & 28 & 40 & 27 & 100 & 3,89 & 389 & Setuju \\
\hline \multicolumn{8}{|c|}{ Rata-rata Skor } & 392,4 & Setuju \\
\hline
\end{tabular}

Sumber: Data diolah 2013 
Tabel 4 menunjukkan dimensi attention dengan skor rata-rata sebesar 392,4 menyatakan setuju. Dengan nilai tertinggi terdapat dalam indikator keempat yaitu tentang perhatian penonton terhadap merek Speedy yang ditampilkan dalam NBL Indonesia dengan nilai skor rentang skala sebesar 414. Skor jawaban setuju sebesar 47 responden atau $47 \%$ dapat disimpulkan bahwa indikator keempat menunjukkan penonton memperhatikan Speedy sebagai brand utama yang menjadi product placement karena brand Speedy sebagai salah satu penyedia layanan broadband akses internet terkemuka di Indonesia yang mensponsori acara NBL Indonesia.

Pada dimensi Acceptance dapat dilihat pada Tabel 5 bahwa dimensi acceptance memiliki skor rata-rata sebesar 410,3 yang menyatakan setuju, dengan item nilai tertinggi pada indikator kontribusi produk tentang penerimaan audience (penonton) atas kontribusi Speedy dalam acara NBL Indonesia dengan nilai rentang skala sebesar 421 menunjukkan kriteria penilaian setuju. Sebagian besar audience memilih setuju sebesar $56 \%$ dan didukung beberapa audience memilih sangat setuju sebesar $33 \%$, dan hanya $1 \%$ yang memilih tidak setuju pada indikator pertama ini. Hasil ini membuktikan bahwa responden memahami dan menerima bahwa Speedy telah berkontribusi dengan sangat baik dalam acara NBL dalam acara NBL Indonesia.

Tabel 6 memberikan informasi mengenai product placement dalam produk Speedy instan card yang digunakan audience (penonton) untuk kepentingan mengikuti perkembangan acara NBL Indonesia. Dimensi reference (pilihan) memiliki skor rata-rata sebesar 356,7 yang menyatakan responden setuju dari hasil keseluruhan indikator dimensi. Sebanyak $46 \%$ responden memilih netral dan $34 \%$ mengatakan setuju. Kesimpulan dengan adanya responden yang lebih banyak memilih netral dibandingkan mengatakan setuju dengan adanya promosi Speedy instan card setiap pembelian tiket NBL Indonesia tidak membuat audience tertarik untuk menggunakan produk Speedy.

Tabel 5. Analisis Rentang Skala dimensi Acceptance (Penerimaan)

\begin{tabular}{|c|c|c|c|c|c|c|c|c|c|}
\hline \multirow{2}{*}{$\begin{array}{c}\text { Respon } \\
(\text { Acceptance })\end{array}$} & \multicolumn{5}{|c|}{ Skor Jawaban } & \multirow{2}{*}{$\begin{array}{c}\text { Total } \\
\mathrm{N}\end{array}$} & \multirow[t]{2}{*}{ Mean } & \multirow{2}{*}{$\begin{array}{c}\text { Skor } \\
\text { Rentang } \\
\text { Skala }\end{array}$} & \multirow{2}{*}{$\begin{array}{l}\text { Kriteria } \\
\text { Penilaian }\end{array}$} \\
\hline & STS & TS & $\mathrm{N}$ & S & SS & & & & \\
\hline $\begin{array}{l}\text { Kontribusi } \\
\text { sponsor }\end{array}$ & 0 & 1 & 10 & 56 & 33 & 100 & 4,21 & 421 & Setuju \\
\hline $\begin{array}{l}\text { Produk tampil } \\
\text { menyatu }\end{array}$ & 0 & 1 & 20 & 50 & 29 & 100 & 4,07 & 407 & Setuju \\
\hline $\begin{array}{l}\text { Penerimaan } \\
\text { sponsor }\end{array}$ & 0 & 1 & 20 & 49 & 30 & 100 & 4,08 & 408 & Setuju \\
\hline $\begin{array}{l}\text { Produk tidak } \\
\text { mengganggu }\end{array}$ & 0 & 3 & 18 & 50 & 29 & 100 & 4,05 & 405 & Setuju \\
\hline \multicolumn{8}{|c|}{ Rata-rata Skor } & 410,25 & Setuju \\
\hline
\end{tabular}

Sumber: Data diolah 2013 
Tabel 6. Analisis Rentang Skala dimensi Reference (Referensi)

\begin{tabular}{|c|c|c|c|c|c|c|c|c|c|}
\hline \multirow{2}{*}{$\begin{array}{c}\text { Respon } \\
\text { (Reference) }\end{array}$} & \multicolumn{5}{|c|}{ Skor Jawaban } & \multirow[t]{2}{*}{$\begin{array}{c}\text { Total } \\
\mathrm{N}\end{array}$} & \multirow[t]{2}{*}{ Mean } & \multirow{2}{*}{$\begin{array}{c}\text { Skor } \\
\text { Rentang } \\
\text { Skala } \\
\end{array}$} & \multirow[t]{2}{*}{$\begin{array}{c}\text { Kriteria } \\
\text { Penilaian }\end{array}$} \\
\hline & STS & TS & $\mathrm{N}$ & $S$ & SS & & & & \\
\hline $\begin{array}{l}\text { Tertarik } \\
\text { menggunakan } \\
\text { produk }\end{array}$ & 3 & 12 & 46 & 34 & 5 & 100 & 3,26 & 326 & Netral \\
\hline $\begin{array}{l}\text { Memanfaatka } \\
\text { n keunggulan } \\
\text { produk }\end{array}$ & 0 & 10 & 40 & 34 & 16 & 100 & 3,56 & 356 & Setuju \\
\hline $\begin{array}{l}\text { Membeli } \\
\text { karena idola }\end{array}$ & 0 & 8 & 22 & 44 & 26 & 100 & 3,88 & 388 & Setuju \\
\hline \multicolumn{8}{|c|}{ Rata-rata Skor } & 356,7 & Setuju \\
\hline
\end{tabular}

Ethics \& Regulations yang terlihat pada Tabel 7 dapat dilihat seberapa besar Speedy dapat memenuhi etika dan peraturan promosi dalam acara NBL Indonesia dengan rata-rata nilai skor rentang skala sebesar 391 menyatakan setuju. Indikator pertama yaitu mengenai promosi Speedy tidak mengganggu jalannya acara NBL Indonesia. Data pada tabel 7 menunjukkan bahwa $46 \%$ responden setuju, dengan didukung $28 \%$ netral dan $22 \%$ sangat setuju, serta hasil nilai indikator menunjukkan nilai sebesar 386 dan kriteria penilaian masuk dalam kategori setuju. Hal ini menunjukkan bahwa respon audience yang menonton beranggapan tidak berpengaruh dan cenderung menerima adanya promosi yang dilakukan Speedy secara langsung maupun melalui product placement dalam NBL Indonesia.

Tabel 7. Analisis Rentang Skala dimensi Ethics and Regulations (Etika dan Peraturan)

\begin{tabular}{|c|c|c|c|c|c|c|c|c|c|}
\hline \multirow{2}{*}{$\begin{array}{c}\text { Respon (Ethics \& } \\
\text { Regulations) }\end{array}$} & \multicolumn{5}{|c|}{ Skor Jawaban } & \multirow[t]{2}{*}{$\begin{array}{c}\text { Total } \\
\mathrm{N}\end{array}$} & \multirow[t]{2}{*}{ Mean } & \multirow{2}{*}{$\begin{array}{c}\text { Skor } \\
\text { Rentang } \\
\text { Skala } \\
\end{array}$} & \multirow[t]{2}{*}{$\begin{array}{r}\text { Kriteria } \\
\text { Penilaian }\end{array}$} \\
\hline & STS & TS & $\mathrm{N}$ & S & SS & & & & \\
\hline $\begin{array}{l}\text { Product placement } \\
\text { tidak mengganggu } \\
\text { acara }\end{array}$ & 0 & 4 & 28 & 46 & 22 & 100 & 3,86 & 386 & Setuju \\
\hline $\begin{array}{l}\text { Product placement } \\
\text { telah mengikuti } \\
\text { tema }\end{array}$ & 0 & 3 & 23 & 49 & 25 & 100 & 3,96 & 396 & Setuju \\
\hline \multicolumn{8}{|c|}{ Rata-rata Skor } & 391 & Setuju \\
\hline
\end{tabular}

Sumber: Data diolah 2013 
Tabel 8. Analisis Rentang Skala dimensi Talking (Pembicaraan)

\begin{tabular}{|c|c|c|c|c|c|c|c|c|c|}
\hline \multirow{2}{*}{$\begin{array}{c}\text { Kesediaan } \\
\text { (Talking) }\end{array}$} & \multicolumn{5}{|c|}{ Skor Jawaban } & \multirow[t]{2}{*}{$\begin{array}{c}\text { Total } \\
\mathrm{N}\end{array}$} & \multirow[t]{2}{*}{ Mean } & \multirow[t]{2}{*}{$\begin{array}{c}\text { Skor } \\
\text { Rentang } \\
\text { Skala }\end{array}$} & \multirow[t]{2}{*}{$\begin{array}{l}\text { Kriteria } \\
\text { Penilaian }\end{array}$} \\
\hline & STS & TS & $\mathrm{N}$ & $\mathrm{S}$ & SS & & & & \\
\hline $\begin{array}{l}\text { Product placement } \\
\text { menjadi } \\
\text { pembicaraan }\end{array}$ & 1 & 11 & 51 & 34 & 3 & 100 & 3,27 & 327 & Netral \\
\hline $\begin{array}{l}\text { Sponsor menjadi } \\
\text { pembicaraan }\end{array}$ & 0 & 12 & 44 & 35 & 9 & 100 & 3,41 & 341 & Netral \\
\hline $\begin{array}{l}\text { Keunggulan } \\
\text { produk menjadi } \\
\text { pembicaraan }\end{array}$ & 1 & 13 & 47 & 32 & 7 & 100 & 3,31 & 331 & Netral \\
\hline \multicolumn{8}{|c|}{ Rata-rata Skor } & 333 & Netral \\
\hline
\end{tabular}

Sumber: Data diolah 2013

Talking adalah pembicaraan yang dilakukan oleh audience tentang sponsor atau product placement yang dalam penelitian ini adalah Speedy atau Speedy instan card dalam acara NBL Indonesia. Pada dimensi talking (pembicaraan) yang dapat dilihat berdasarkan Tabel 8 dengan skor ratarata sebesar 333 dengan penilaian netral. Dapat disimpulkan bahwa responden atau audience yang menonton lebih memilih tidak melakukan pembicaraan dan cenderung biasa saja dengan adanya promosi yang dilakukan Speedy melalui product placement dalam acara NBL Indonesia.

Tabel 9 menunjukkan bahwa item dengan nilai indikator tertinggi tentang pempromosian Speedy instan card digunakan untuk live streaming NBL Indonesia. Berdasarkan tabel sebagian besar konsumen memilih setuju, yang dipilih oleh 56 responden. Lebih dari setengah jumlah responden menyatakan setuju dengan skor indikator sebesar 380 . Hal ini membuktikan responden bersedia melakukan pempromosian Speedy instan card kepada teman

Tabel 9. Analisis Rentang Skala dimensi Promoting (Pempromosian)

\begin{tabular}{|c|c|c|c|c|c|c|c|c|c|}
\hline \multirow{2}{*}{$\begin{array}{l}\text { Kesediaan } \\
\text { (Promoting) }\end{array}$} & \multicolumn{5}{|c|}{ Skor Jawaban } & \multirow[t]{2}{*}{$\begin{array}{c}\text { Total } \\
\mathrm{N}\end{array}$} & \multirow[t]{2}{*}{ Mean } & \multirow[t]{2}{*}{$\begin{array}{c}\text { Skor } \\
\text { Rentang } \\
\text { Skala }\end{array}$} & \multirow[t]{2}{*}{$\begin{array}{l}\text { Kriteria } \\
\text { Penilaian }\end{array}$} \\
\hline & STS & $\mathrm{TS}$ & $\mathrm{N}$ & S & SS & & & & \\
\hline $\begin{array}{l}\text { Pempromosian } \\
\text { keunggulan } \\
\text { produk }\end{array}$ & 1 & 4 & 24 & 56 & 15 & 100 & 3,80 & 380 & Setuju \\
\hline $\begin{array}{l}\text { Pempromosian } \\
\text { menjadi lifestyle }\end{array}$ & 1 & 8 & 41 & 42 & 8 & 100 & 3,48 & 348 & Setuju \\
\hline $\begin{array}{l}\text { Pempromosian } \\
\text { menarik } \\
\text { konsumen }\end{array}$ & 2 & 6 & 33 & 44 & 15 & 100 & 3,64 & 364 & Setuju \\
\hline \multicolumn{8}{|c|}{ Rata-rata Skor } & 364 & Setuju \\
\hline
\end{tabular}

Sumber: Data diolah 2013 
Tabel 10. Analisis Rentang Skala dimensi Selling (Penjualan)

\begin{tabular}{|c|c|c|c|c|c|c|c|c|c|}
\hline \multirow{2}{*}{$\begin{array}{l}\text { Kesediaan } \\
\text { (Selling) }\end{array}$} & \multicolumn{5}{|c|}{ Skor Jawaban } & \multirow[t]{2}{*}{$\begin{array}{c}\text { Total } \\
\mathrm{N}\end{array}$} & \multirow[t]{2}{*}{ Mean } & \multirow{2}{*}{$\begin{array}{c}\text { Skor } \\
\text { Rentang } \\
\text { Skala } \\
\end{array}$} & \multirow[t]{2}{*}{$\begin{array}{r}\text { Kriteria } \\
\text { Penilaian }\end{array}$} \\
\hline & STS & TS & $\mathrm{N}$ & $\mathrm{S}$ & SS & & & & \\
\hline $\begin{array}{l}\text { Rekomendasi } \\
\text { produk }\end{array}$ & 0 & 3 & 26 & 47 & 24 & 100 & 3,92 & 392 & Setuju \\
\hline $\begin{array}{l}\text { Penjualan } \\
\text { produk menarik } \\
\text { audience }\end{array}$ & 0 & 4 & 39 & 37 & 20 & 100 & 3,73 & 373 & Setuju \\
\hline $\begin{array}{l}\text { Special Edition } \\
\text { Product }\end{array}$ & 1 & 6 & 28 & 41 & 24 & 100 & 3,81 & 381 & Setuju \\
\hline \multicolumn{8}{|c|}{ Rata-rata skor } & 382 & Setuju \\
\hline
\end{tabular}

Sumber: Data diolah 2013

/kerabat yang digunakan untuk menonton acara live streaming NBL Indonesia dengan mudah dimanapun dan kapapun.

Pada dimensi selling (penjualan) yang dilihat dari Tabel 10 bahwa item dengan nilai indikator tertinggi yaitu Speedy merekomendasikan product placement Speedy instan card kepada audience NBL Indonesia. Hal ini menunjukkan bahwa Speedy telah melakukan rekomendasi product placement dengan baik kepada audience NBL Indonesia, sehingga produk Speedy instan card dapat digunakan audience untuk menikmati layanan wifi internet di tempat berlangsungnya acara NBL Indonesia.

Hasil Uji Asumsi Klasik pada Uji Multikolinieritas untuk perhitungan nilai Variance Inflator Factor (VIF) pada Tabel 11 menunjukkan variabel independen memiliki nilai VIF berada disekitar angka 1 dan tidak lebih dari 10. Jadi, dapat disimpulkan bahwa tidak ada multikolinieritas di dalam model regresi.

Hasil Uji Heteroskedastisitas dari perhitungan yang terdapat pada Tabel 12 menunjukkan variabel telah memenuhi syarat uji heteroskedastisitas, dimana nilai signifikansi yang diperoleh lebih besar dari 0,05. Sedangkan pada Uji Autokorelasi pada Tabel 13 menunjukkan bahwa variabel telah memenuhi syarat uji autokorelasi, sehingga variabel tersebut independen (tidak ada masalah autokorelasi) yang ditunjukkan dengan range $(\mathrm{du}<\mathrm{dw}<4-\mathrm{du})=$ $(1,70<1,89<2,30)$ dan angka Durbin Watson mendekati angka 2 yaitu sebesar 1,89.

Hasil uji KolmogorovSmirnov menunjukkan, diperoleh nilai signifikansi sebesar $0,528>0,05$ dan penyebaran data (titik) pada Gambar 1 menyebar disekitar garis diagonal dan mengikuti arah garis diagonal ke atas. Dapat disimpulkan bahwa model regresi telah memenuhi asumsi normalitas. 
Tabel 11. Uji Multikolinieritas

\begin{tabular}{lccc}
\hline \multicolumn{1}{c}{ Variabel } & Nilai & Nilai & Keterangan \\
Independen & Tolerance & VIF & \\
\hline Product & 1,000 & 1,000 & Tidak terjadi \\
Placement & & Multikolinieritas \\
(X) & & \\
\hline \multicolumn{2}{c}{ Sumber: Data Diolah } & &
\end{tabular}

Tabel 12. Uji Heteroskedastisitas

\begin{tabular}{|c|c|c|c|}
\hline $\begin{array}{c}\text { Variabel } \\
\text { Independen }\end{array}$ & $\mathrm{r}$ & Sig & Keterangan \\
\hline $\begin{array}{l}\text { Product } \\
\text { Placement } \\
\text { (X) }\end{array}$ & $-0,056$ & 0,582 & Homoskedastisitas \\
\hline
\end{tabular}

Tabel 13. Uji Autokorelasi

\begin{tabular}{cccccc}
\hline $\mathrm{dl}$ & $\mathrm{du}$ & $4-\mathrm{du}$ & $4-\mathrm{dl}$ & $\mathrm{dw}$ & Keterangan \\
\hline 1,65 & 1,70 & 2,30 & 2,35 & 1,89 & $\begin{array}{c}\text { Tidak ada } \\
\text { autokorelasi }\end{array}$
\end{tabular}

Sumber: Data Diolah

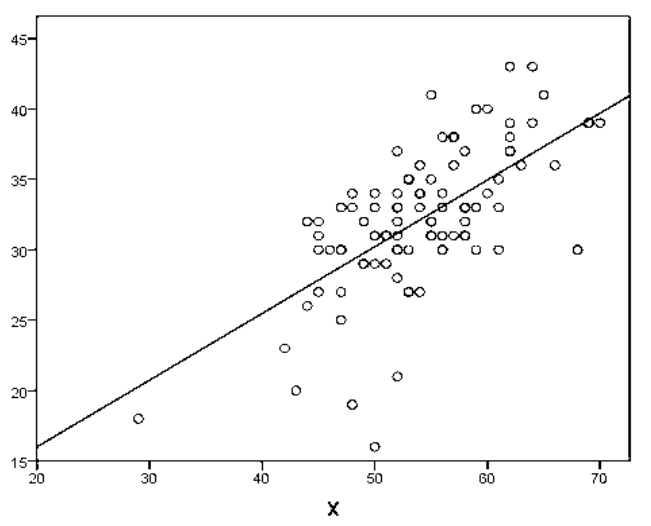

Gambar 1. Grafik Normalitas

Tabel 14. Koefisien Determinasi

\begin{tabular}{|c|c|c|c|c|}
\hline \multicolumn{5}{|c|}{ Model Summary ${ }^{b}$} \\
\hline Model & $\mathrm{R}$ & $\begin{array}{c}\mathrm{R} \\
\text { Squar } \\
\mathrm{e}\end{array}$ & $\begin{array}{c}\text { Adjuste } \\
\text { d R } \\
\text { Square }\end{array}$ & $\begin{array}{c}\text { Std. } \\
\text { Error of } \\
\text { the } \\
\text { Estimate }\end{array}$ \\
\hline 1 & $.647^{\mathrm{a}}$ & .419 & .413 & 3.878 \\
\hline & $\begin{array}{l}\text { Data D } \\
\text { Berda }\end{array}$ & $\begin{array}{l}\text { olah } \\
\text { arkan }\end{array}$ & Tabe & 14 \\
\hline
\end{tabular}

Square adalah 0,413. Angka Adjusted $R$ Square disebut juga sebagai koefisien determinasi. Besarnya angka koefisien determinasi 0,413 atau $41,3 \%$, angka tersebut berarti bahwa sebesar $41,3 \%$ dari word of mouth yang terjadi dapat dijelaskan menggunakan product placement. Sedangkan sisanya sebesar $58,7 \%$ (100\%-41,3\%) dapat dijelaskan oleh variabel lain diluar variabel bebas (product placement) tersebut, yang tidak dimasukkan dalam model.

Berdasarkan hasil pengukuran regresi yang ditunjukkan pada tabel 15. Maka persamaan regresi linier sederhana yang terbentuk berdasarkan hasil analisis diatas adalah sebagai berikut:

$\hat{\mathrm{Y}}=\mathrm{bX}$

$\hat{Y}=0,647 X$

Persamaan regresi tersebut menunjukkan pengaruh product placement (X) terhadap word of mouth (Y) adalah searah atau positif. Artinya, semakin besar perhatian (attention) audience, penerimaan (acceptance), mereferensikan (reference), serta mengetahui etika dan peraturan (ethics \& regulations) dalam acara NBL Indonesia maka audience semakin bersedia melakukan word of mouth (bersedia melakukan talking, promoting, dan selling) atas product placement Speedy.

Pembuktikan apakah variabel product placement yang dimasukkan dalam model mempunyai pengaruh signifikan secara bersama-sama terhadap variabel terikat dilakukan dengan digunakan uji $\mathrm{F}$ pada Tabel 16. Dengan tingkat kepercayaan sebesar $95 \%$ atau taraf signifikansi sebesar 5\% maka: Jika $\mathrm{F}_{\text {hitung }}>\mathrm{F}_{\text {tabel }}$ maka $\mathrm{H}_{0}$ ditolak, berarti variabel 
bebas secara bersama-sama mempunyai pengaruh yang positif dan bermakna terhadap variabel terikat.

Pengujian ini membuktikan $\mathrm{H}_{1}$ diterima, yang ditunjukkan dengan besarnya $F_{\text {hitung }}$ sebesar 70,555. Nilai ini jauh lebih besar dari $F_{\text {tabel }}$ yaitu $(70,555>3,94)$. Dengan $F_{\text {hitung }}$ sebesar 70,555 dengan signifikansi $\mathrm{F}$ 0,000 dan $\mathrm{df}=\mathrm{n}-\mathrm{k}-1=100-1-1=98$ diperoleh $\mathrm{F}_{\text {tabel }}$ sebesar 3,94. Karena probabilitas jauh lebih kecil dari 0,005 dan $F_{\text {hitung }}>F_{\text {tabel }}$ maka model regresi dapat digunakan untuk memprediksi word of mouth atau dapat dikatakan bahwa product placement berpengaruh positif dan bermakna terhadap word of mouth.

Indikator di dalam dimensi adalah memperhatikan sponsor Speedy, memperhatikan logo Speedy, kesesuaian konsep acara NBL Indonesia, dan memperhatikan brand Speedy sebagai merek utama yang ditampilkan dalam acara NBL Indonesia. Berdasarkan keseluruhan indikator dapat disimpulkan bahwa perhatian terhadap product placement, dapat dilihat bagaimana suatu produk dapat ditampilkan dengan menunjukkan identitas (brand/ logo) dari produk untuk memberikan karakteristik merek pada produk tersebut.

Indikator dari acceptance dapat disimpulkan bahwa penerimaan akan didapat apabila product placement atau sponsor dapat diaplikasikan sesuai dengan konsep dan alur acara, karena hal itu dapat menguatkan keberadaan produk yang nantinya akan menarik perhatian audience. Pada indikator reference yaitu menggunakan produk karena telah dijadikan product placement dalam acara NBL Indonesia, kurang menarik perhatian audience, karena audience kurang tertarik browsing internet menggunakan Spin Card pada saat acara berlangsung. Audience murni datang dengan antusiasme menonton pertandingan NBL Indonesia, sehingga product placement Spin Card teralihkan dengan acara NBL.

Tabel 15. Hasil Analisis Regresi

Coefficients $^{\mathbf{a}}$

\begin{tabular}{|c|c|c|c|c|c|c|c|c|}
\hline \multirow[b]{2}{*}{ Model } & \multicolumn{3}{|r|}{$\begin{array}{l}\text { Std. } \\
\text { Coeff }\end{array}$} & \multirow[t]{2}{*}{$\mathrm{t}$} & \multirow[t]{2}{*}{ Sig. } & \multicolumn{3}{|c|}{ Correlations } \\
\hline & $\mathrm{B}$ & $\begin{array}{l}\text { Std. } \\
\text { Error }\end{array}$ & Beta & & & $\begin{array}{l}\text { Zero- } \\
\text { order }\end{array}$ & Partial & Part \\
\hline (Constant) & 6.533 & 3.10( & & 2.1 & .038 & & & \\
\hline $\begin{array}{l}\text { Product } \\
\text { Placement }\end{array}$ & .474 & $.05 t$ & .647 & 8.4 & .000 & .647 & .647 & 7.647 \\
\hline
\end{tabular}

Tabel 16. Pengujian Hipotesis

\begin{tabular}{llcclll}
\hline \multicolumn{3}{c}{ Hipotesis Alternatif $\left(\mathrm{H}_{1}\right)$} & df & \multicolumn{1}{c}{ Nilai } & Keterangan \\
\hline Terdapat pengaruh yang positif dan & 1 & $\mathrm{~F}$ & $=70,555$ & $\mathrm{H}_{1}$ diterima/ \\
signifikan secara simultan pada variabel & 98 & Sig F $=0,000$ & $\mathrm{H}_{0}$ ditolak \\
product placement terhadap word of mouth. & 99 & $\mathrm{~F}_{\text {tabel }}=3,94$ &
\end{tabular}

Sumber: Data Diolah 
Etika dan peraturan akan melihat bagaimana sponsor/product placement digunakan semestinya sesuai peraturan terhadap media iklan dan sponsor dalam acara. Audience dari suatu acara akan terganggu apabila promosi yang dilakukan sponsor melebihi peraturan terhadap penggunaan product placement sebagai media iklan. Pada dimensi talking audience kurang bersedia melakukan pembicaraan terkait product placement karena produk dari sponsor kurang sesuai dengan tema acara. Dapat disimpulkan bahwa talking merupakan terciptanya suatu topik yang mendorong audience untuk melakukan pembicaraan dengan orang lain karena adanya ketertarikan terhadap product placement atau keunggulan produk Speedy yang di tampilkan dalam acara NBL Indonesia.

Pempromosian terjadi apabila audience menggunakan produk yang menjadi product placement karena adanya keunggulan produk dengan kecepatan internet wifi.id dari Speedy yang dapat digunakan untuk live streaming NBL Indonesia dimana saja. Selling pada penelitian ini digambarkan bagaimana sponsor dapat mempromosikan suatu acara dengan mempromosikan acara tersebut melalui product placement yang dilakukan sebagai media iklan didalam acara liga nasional.

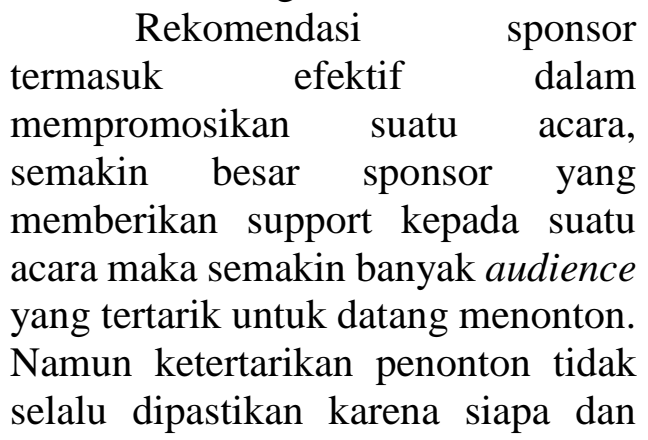

produk apa yang ditawarkan oleh sponsor.

\section{SIMPULAN}

$\begin{array}{llr}\quad \text { Hasil } & \text { rentang } & \text { skala per- } \\ \text { indikator } & \text { dimensi } & \text { tersebut } \\ \text { menunjukkan } & \text { audience } & \text { NBL }\end{array}$ memberikan respon positif/setuju terhadap product placement yang dilakukan oleh Speedy apabila sponsor dapat memberikan kontribusi yang baik terhadap acara. Hal tersebut dikarenakan ketertarikan audience terhadap product placement tidak lepas dari kecintaan audience terhadap acara NBL Indonesia yang mampu mengikuti alur sesuai konsep sehingga audience dapat menerima keberadaan sponsor didalam acara.

Kesediaan penonton terkait word of mouth Speedy, dapat dilihat pada hasil rentang skala dalam dimensi talking, promoting, dan selling. Dapat disimpulkan bahwa audience bersedia melakukan word of mouth jika hal tersebut memiliki keterkaitan dalam memeriahkan acara NBL Indonesia.

Berdasarkan hasil analisis regresi menunjukkan bahwa product placement Speedy memiliki pengaruh yang positif dan signifikan secara simultan terhadap word of mouth audience, namun pengaruhnya cenderung lemah. Audience lebih berfokus pada acara, sehingga product placement kurang menarik minat penonton NBL Indonesia.

\section{DAFTAR PUSTAKA}

Abdi, Dicky. 2013. "Review Dunia Dalam Genggamanmu di Metro TV 13 Oktober 2013". http://blog.ub.ac.id/dickysety a/2013/10/13/review-duniadalam-genggamanmu-13- 
oktober-2013tahun-ini-untuk-

ketiga-kalinya-secara-

berturut-turut-telkom-

sebagai-perusahaan-

telekomunikasi-ternama-di-

indonesia-dipercaya-untuk-

menjadi-pendukung-utam/.

Oktober, 14, 2013.

Argan, M., Vlioglu, M. N., Argan, M.

T., 2007. Audience Attitudes

Towards Product Placement

in Movies: A Case from

Turkey". The Journal of

American Academy of

Business-Cambridge, 11, pp. 161-167.

Armstrong, dan Kotler 2003, Dasardasar Pemasaran, Jilid 1, Edisi Kesembilan, Penerbit PT. Indeks Gramedia, Jakarta.

Atkinson, Claire. 2004. It's The Marketer Apprentice. Advertising Age, pp 1, 35, 75.

Balasubramanian, Siva. K. 1994. Beyond Advertising and Promotion: An Integrated Marketing Communications Perspective, $6^{\text {th }}$ Edition. New York: Mc Graw Hill.

Belch, G. B. 2012. Advertising an Promotion: An Integrated Marketing Communication Perspective. New York: Mc Graw Hill.

Belch, George.E \& Belch, Michael A. 2007. Advertising and Promotion: An Integrated Marketing Communication Perspective, $7^{\text {th }}$ Edition. New York: Mc Graw Hill.

D'Astous, A. and F. Chartier (2000), "A Study of Factors Affecting Consumer Evaluations and Memory of Product Placements in Movies," Journal of Current Issues and
Research in Advertising, 22, 2, 31-40.

Gupta, pola B and Gould, SJ. 1997. Consumer Perception of The Ethics and Acceptability of product Placement in Movies: Product Category and Individual Differences. Journal of Current Issues and Research in Advertising. 14. 37-50.

Gutnik, Lilia et al. 2007. New Trends in Product Placement. Strategic Computing and Communications Technology.

Handayani. 2010. "Kekuatan Word of Mouth (WOM) dalam Strategi Pemasaran". www. Shcribb.com. Online. Diakses 10 Oktober 2013.

Harsasi, M. 2006. Word of Mouth dalam Industri Jasa Kaitannya Dengan Sikap dan Kemungkinan Membeli. Jurnal Bisnis Strategi. Fakultas Ekonomi dan Bisnis: Universitas Gajah Mada.

Mangold, WG dkk. 1999. Word of Mouth Communication in the Service Marketplace. Journal of Services Marketing. Online.

www.emeraldinsight.com. Diakses 12 Oktober 2013.

Morton, C. R \& Friedman, M., 2002, "I Saw it on The Movies: Exploring The Link Between Product Placement Beliefs and Reported Usage Behavior". Journal of Current Issues and Research in Advertising, 24, 2, pp. 33-40.

Purbarani, Meitasari. 2013. Pengaruh Komunikasi Word of Mouth Smartphone Blackberry 
Terhadap Keputusan

Pembelian (Studi Kasus pada

Mahasiswa Eksistensi

Program Studi Manajemen

Fakultas Ekonomi

Universitas Pasundan

Bandung tahun 2009-2012).

Skripsi. Fakultas Ekonomi

Program Studi Manajemen:

Universitas Pasundan

Bandung.

Rumambi, Leonid dan Evy Tandiono.

2013. Analisa Pengaruh

Product Placement dan Brand
Recall Volvo Terhadap Sikap konsumen dalam Film "Twilight

Saga: Breaking Dawn (Part 2)

Vol 1 No 1. Fakultas Ekonomi:

Universitas Kristen Petra

Surabaya.

Sugiyono, 2004. Metode Penelitian Bisnis. Bandung: CV. Alfabeta. 2007. Metode Penelitian Bisnis dan Ekonomi. Bandung: CV Alfabeta.

Widayat \& Amirullah, 2002. Riset Bisnis. Graha Ilmu: Yogyakarta. 